\title{
Conceptual Model for Simulating the Adjustments of Bankfull Characteristics in the Lower Yellow River, China
}

\author{
Yuanjian Wang, ${ }^{1,2}$ Xudong Fu, ${ }^{1}$ and Guangqian Wang ${ }^{1}$ \\ ${ }^{1}$ State Key Laboratory of Hydroscience and Engineering, Tsinghua University, Beijing 100084, China \\ ${ }^{2}$ Yellow River Institute of Hydraulic Research, Yellow River Conservancy Commission, Zhengzhou 450003, China \\ Correspondence should be addressed to Yuanjian Wang; wang-yj03@mails.tsinghua.edu.cn
}

Received 23 December 2013; Revised 7 February 2014; Accepted 12 May 2014; Published 5 August 2014

Academic Editor: Yuefei Huang

Copyright (c) 2014 Yuanjian Wang et al. This is an open access article distributed under the Creative Commons Attribution License, which permits unrestricted use, distribution, and reproduction in any medium, provided the original work is properly cited.

\begin{abstract}
We present a conceptual model for simulating the temporal adjustments in the banks of the Lower Yellow River (LYR). Basic conservation equations for mass, friction, and sediment transport capacity and the Exner equation were adopted to simulate the hydrodynamics underlying fluvial processes. The relationship between changing rates in bankfull width and depth, derived from quasiuniversal hydraulic geometries, was used as a closure for the hydrodynamic equations. On inputting the daily flow discharge and sediment load, the conceptual model successfully simulated the 30-year adjustments in the bankfull geometries of typical reaches of the LYR. The square of the correlating coefficient reached 0.74 for Huayuankou Station in the multiple-thread reach and exceeded 0.90 for Lijin Station in the meandering reach. This proposed model allows multiple dependent variables and the input of daily hydrological data for long-term simulations. This links the hydrodynamic and geomorphic processes in a fluvial river and has potential applicability to fluvial rivers undergoing significant adjustments.
\end{abstract}

\section{Introduction}

The bankfull characteristics of alluvial rivers are basic research topics in fluvial processes $[1,2]$. In recent years, various natural and anthropogenic disturbances (such as dam construction, water and soil conservation, enhanced water usage with rapid socioeconomic development, and evaporation and precipitation variation related to climate change) have altered the runoff and sediment yield in many large river basins. Concerns have been raised regarding adjustments to river geometries and their impacts on local flood defence and ecological safety. There is emerging interest in the temporal adjustment of bankfull characteristics for rivers subject to significant climate change or intense human interference [3].

Two kinds of approaches have been developed to quantify the variation in bankfull characteristics in terms of the timescales at which the channel adjustment is explored: geomorphic and hydrodynamic approaches. The geomorphic approach is usually based on geomorphic laws expressed by power law, hyperbolic, and exponential equations or relatively complex differential equations [4-7]. It is widely recognised that geomorphic systems respond rapidly, immediately following the disruption of the equilibrium state, but thereafter exhibit a declining rate of adjustment as a new equilibrium or relaxed state is approached $[5,8,9]$. Applications with years or decades of geomorphic models can be found for various alluvial river basins, such as the South Island of New Zealand [10], Lower Hunter Valley in NewSouthWales [11], sand-bed streams of the American Midwest [12], Sabie River in South Africa [13], Karst landscape evolution in the Cave City in Kentucky [14], Lower Yellow River (LYR) in China [15-18], basins in southeastern Australia [19], and North Fork Toutle River in Washington [20]. The river channel slope [21], channel width [22], bankfull cross-section area and discharge $[16,17]$, bed level $[9,23]$, and channel width-depth ratio [24] have been considered as dependent variables of flow and the sediment volume flux per year.

The hydrodynamic approach reproduces channel response processes by accounting for microscale river dynamics. That is, the Saint Venant equations (continuity and momentum equations) for river flow, the sediment transport equation, and the river bed or bank deformation equations are set up to describe the instantaneous relations 


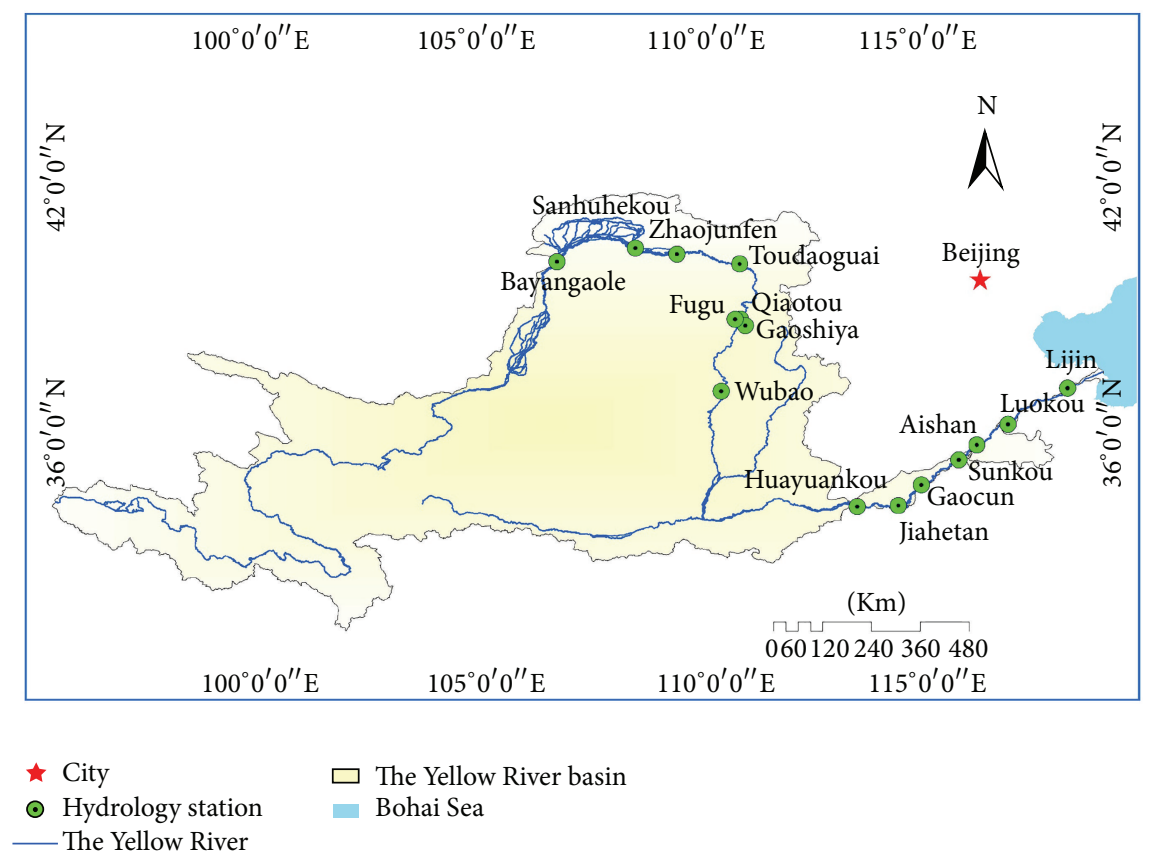

Figure 1: Schematic of the Yellow River basin.

between channel adjustment and the incoming flow and sediment conditions. One-, two-, and three-dimensional models for either steady flow [25-29] or unsteady flow [3032] have been used widely to investigate channel degradation or aggradation during flood events. Recently, much effort has shifted to the long-term simulation of channel responses. The formation and evolution of meandering or wandering rivers has been simulated considering the long-term fluvial actions [33-36]. For example, Sun et al. [34] reproduced the phenomenon of channel evolution, including the shallowing and widening of the initial channel, the rhythmical sequence of alternate bars and erosional bumps, and the occurrence of meandering abrupt shifts and bank cusps. Asahi et al. [36] captured the nature process of river meandering in a computational model that considers the effects of bank erosion, the process of land accretion along the inner banks of meander bends, and the formation of channel cut-offs.

In nature, the channel response is achieved by the cumulative effects of fluvial erosion/deposition processes, which relate to both geomorphic processes and hydrodynamic events. The geomorphic approach, particularly the rate law method, can capture the overall behaviour of the channel response to seasonal or annual flow and sediment data, but it cannot account for the effects of flood events. The channel response can be characterised by a set of variables, but the coordination of multiple dependent variables has not been explored. By contrast, the hydrodynamic approach is capable of representing the details of the channel response process at small timescales, such as bank erosion, bar migration, and channel shallowing/widening. When applied on large timescales, the computational limitations and requirements for accurate resistance parameters and boundary conditions may stop it from producing reliable simulation and predictions.

Here we propose a physics-based model linking hydrodynamic and geomorphic scales. It is intended to represent channel response processes subject to both hydrodynamic and geomorphic controls. The model adopts hydrodynamic equations and boundary equations with daily data as input. It enables the characterisation of flood events in large rivers (typically lasting for around 10 days) and the simulation of continuous response behaviour over a long-term period (years or decades). In a scientific sense, linking across hydrodynamic and geomorphic scales is an attempt to overcome the shortcomings of each scale by considering the flood details and obtaining the long-period channel response processes. It may be applied both to simulate fluvial processes over the past few decades and to forecast channel-forming processes with potential flow and sediment series in the future for large alluvial rivers like LYR.

\section{Background of This Study}

2.1. Overview of the Study Area. The Yellow River is the second longest river in China and supports $12 \%$ of the Chinese population (Figure 1). The river is about $5464 \mathrm{~km}$ long with a drainage area of $752,000 \mathrm{~km}^{2}$. The Yellow River is famous for its excessive sediment load and deficient flow. The long-term average sediment load at the Sanmenxia Dam is 1.6 billion tons per year, which ranks first in the world.

The LYR stretches from Huayuankou to Lijin, as shown in Figure 2. It is about $520 \mathrm{~km}$ long and exhibits variable channel patterns. It is usually divided into three geomorphological distinct reaches [37]. The upper reach from Huayuankou to 

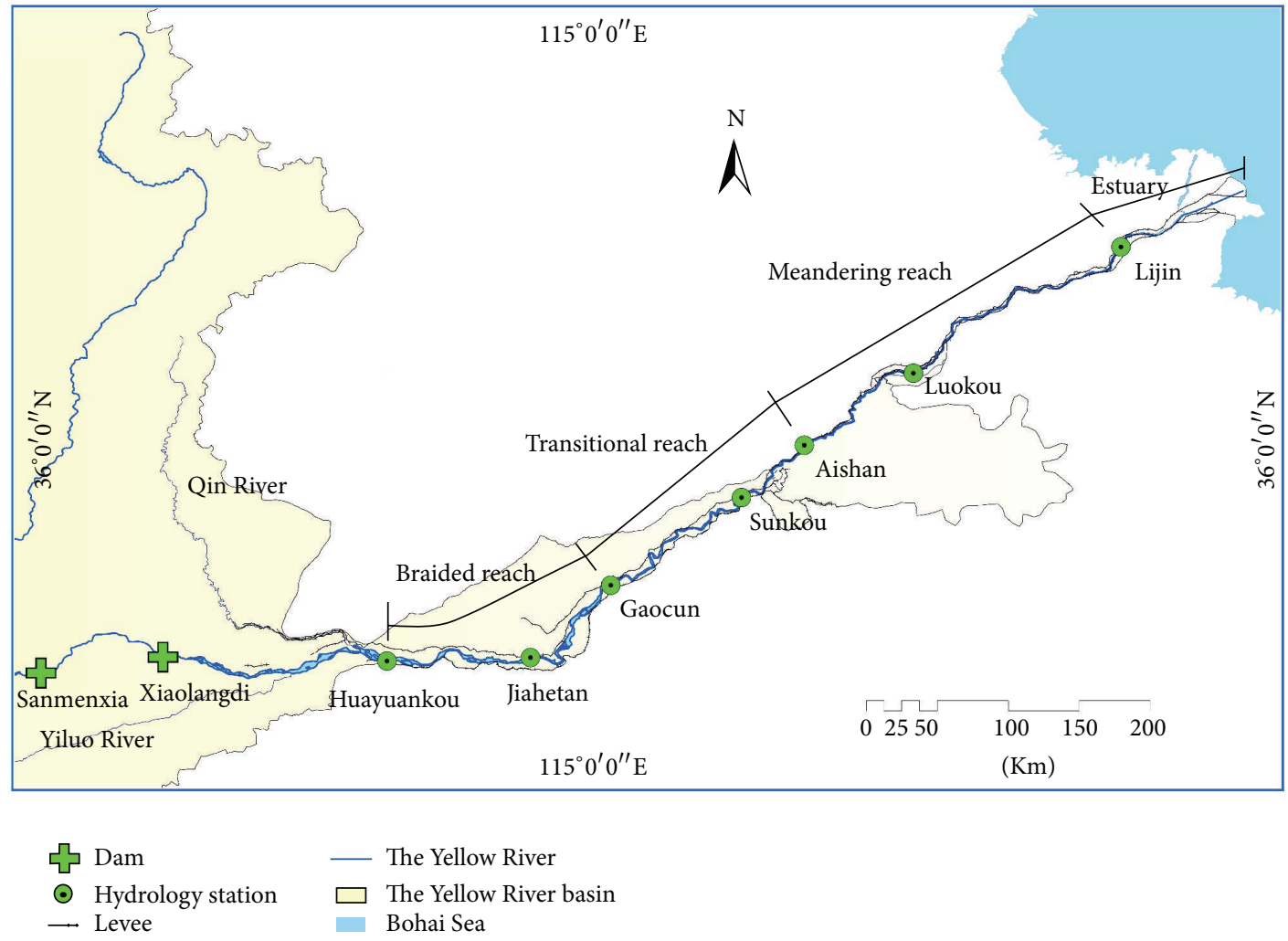

FIgURE 2: Map of the Lower Yellow River.

Gaocun is a typical wandering channel pattern. The lower reach, from Taochengpu to Lijin, is a stable meandering channel pattern. The intervening reach transitions from wandering to meandering. The LYR is a natural alluvial river because of the high suspended sediment load it carries and deposits. According to the observed data, the total deposition volume in the LYR reached about 5.52 billion $\mathrm{m}^{3}$ during the period from 1950 to 1999 , of which $60 \%$ was deposited in the wandering reach.

Here, the Huayuankou and Lijin Stations were chosen to validate the effects of the model, because these two stations are representative of typical wandering and meandering reaches, respectively. They have different bankfull characteristics as a function of flow and sediment load.

For Lijin Station in the meandering reach, the bankfull characteristics are easy to determine by observing when the water fills the main channel without overtopping the banks of the floodplain (Figure 3). For Huayuankou Station, cross-sections usually exhibit a compound geometric shape (Figure 4). Given nonstationary flow and sediment discharge, the location of the main channel often shifts laterally, which makes it difficult to define the zone of the main channel and bankfull characteristics in the wandering reach. As before, earlier and later measurements of the cross-section and the upstream and downstream cross-sectional profiles were used for reference to determine the bankfull stage [32].
Lijin cross-section (May 16th, 1993 )

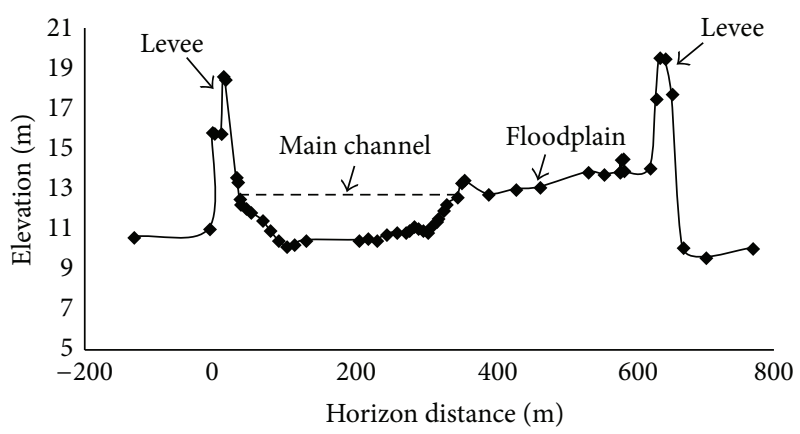

FIgURE 3: Typical cross-sectional profile at Lijin Station.

The deviation of the inner-annual distributions of flow and sediment discharge can cause different channel forms in the LYR. These two chosen reaches had similar annual mean values of flow and sediment discharge, but different annual distributions (Figure 5). The annual mean flow discharge from 1950 to 2002 was $1248 \mathrm{~m}^{3} / \mathrm{s}$ at Huayuankou Station and $1036 \mathrm{~m}^{3} / \mathrm{s}$ at Lijin Station, while the annual peak flow discharge (daily peak data) was 6014 and $4713 \mathrm{~m}^{3} / \mathrm{s}$, respectively. The annual mean sediment discharge from 1950 to 2002 was $32 \mathrm{~m}^{3} / \mathrm{s}$ at Huayuankou Station and $26 \mathrm{~m}^{3} / \mathrm{s}$ at Lijin Station, 


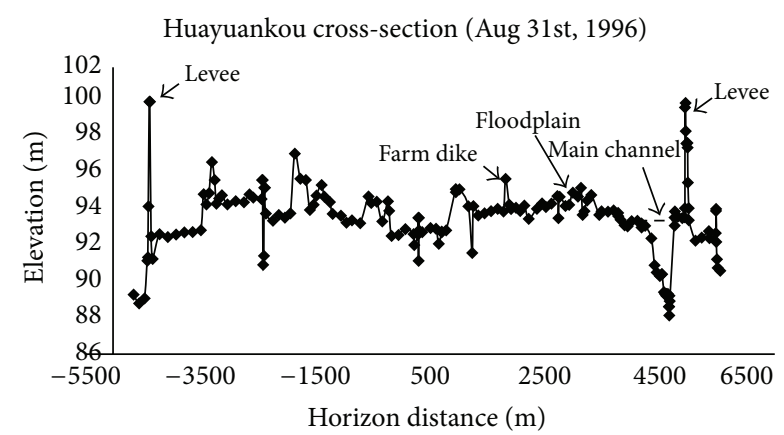

Figure 4: Typical cross-sectional profile at Huayuankou Station.

while the annual peak sediment discharge (daily peak data) was 653 and $330 \mathrm{~m}^{3} / \mathrm{s}$, respectively.

Using time series analysis, a decreasing trend was detected for the annual mean and daily peak flow and sediment discharge for the two stations over the past 50 years using the Mann-Kendall method [38]. Two significant times marking mutation of the pattern of the annual mean flow discharge were detected at the stations (1969 and 1986) using the Fisher discriminant criterion [39]. The two years were linked to dam construction on the Yellow River for the Liujiaxia and Longyangxia reservoirs.

2.2. Bankfull Characteristics in Typical Sections. Figure 6 shows the observed bankfull characteristics (bankfull discharge $Q_{\mathrm{bf}}$, bankfull area $A_{\mathrm{bf}}$, bankfull width $B_{\mathrm{bf}}$, and bankfull depth $h_{\mathrm{bf}}$ ) at Lijin Station from 1964 to 2000 . All of the data were obtained from the measured profile data after the flood season each year. Table 1 shows the correlation matrix. From the figure and table, there are linear relations between $Q_{\mathrm{bf}}$ and $A_{\mathrm{bf}}, A_{\mathrm{bf}}$ and $h_{\mathrm{bf}}$, and $\mathrm{Q}_{\mathrm{bf}}$ and $A_{\mathrm{bf}}$. However, the data mining indicated that the bankfull width $B_{\mathrm{bf}}$ varied from 400 to $600 \mathrm{~m}$. For this, there were no obvious linear relations. Since these bankfull characteristics were all determined by the incoming flow and sediment conditions on a large time scale; there is no coherent geomorphic law to interpret all processes.

The same analysis for Huayuankou in the wandering reach is shown in Figure 7 and Table 2. Nonlinear relations existed more widely here than at Lijin. Except for $A_{\mathrm{bf}} \sim$ $h_{\mathrm{bf}}$, none of the other relationships were obviously linear. The channel geometry changed so quickly and markedly that the bankfull width $B_{\mathrm{bf}}$ varied from 1800 to $3200 \mathrm{~m}$. This showed greater variation and was more nonlinear than in the meandering reach.

\section{Study Methodology}

In previous geomorphic models, channel response to disturbances can be described using nonlinear decay functions, for which the rate law has been most widely used to describe relaxation paths and recovery times. The rate law takes the form of a negative exponential equation:

$$
\frac{d Y}{d t}=-\beta\left(Y-Y_{e}\right)
$$

Here, $Y$ is a characteristic parameter of the fluvial system, $Y_{e}$ is the asymptotic value of this parameter, $\beta$ is the decay rate that quantifies how rapidly $Y$ approaches $Y_{e}$, and $t$ is the time since the disturbance. Many studies have shown that the rate law can simulate and predict the channel response to disturbances with seasonal or annual data [5, 40-42].

As mentioned above, the rate law is used to illustrate the channel forming macroprocess $\left(10^{1}-10^{2}\right.$ years $)$ without any physical mechanism. It smoothes the flood details and cannot account for the effects of the deviation of flood events. This paper focuses on the dynamic processes of the channel geometry of alluvial rivers. Bankfull parameters such as the bankfull discharge $Q_{\mathrm{bf}}$, area $A_{\mathrm{bf}}$, width $B_{\mathrm{bf}}$, and depth $h_{\mathrm{bf}}$ all vary with time. To capture the major characteristics of the fluvial response, but allow lower computational complexity, a quasiequilibrium state was assumed. The temporal variation of the flow discharge and sediment load was distinguished for typical flood events, but the governing equations of flow and sediment transport took the form for steady flows. This suggests an intermediate timescale between the hydrodynamic and geomorphic scales. Above this, the temporal variation is accounted for, but it is neglected below this. A suitable timescale for a large river like the LYR that has a typical flood event of 10 days is 1 day. This can account for the daily variation in the flow and sediment conditions during the flood event.

The cross-sections of the LYR are mostly wide and shallow with 400-4000 $\mathrm{m}$ river top widths and 1-5 m river depths. As a result, the wetted perimeter $p(\mathrm{~m})$ can nearly be substituted by the top widths $B(\mathrm{~m})$. The hydraulic radius $R(\mathrm{~m})$ can be expressed as $R=A / p=A / B=h$, where $A$ is the flow area $\left(\mathrm{m}^{2}\right)$ and $h(\mathrm{~m})$ is the average river depth expressed by $h=A / B$. With the assumption of quasiequilibrium [43, 44], the flow continuity, momentum, sediment transport, and bed deformation equations can be expressed as

$$
\begin{gathered}
Q_{\mathrm{bf}}=B_{\mathrm{bf}} h_{\mathrm{bf}} U_{\mathrm{bf}}, \\
U_{\mathrm{bf}}=\frac{1}{n} R_{\mathrm{bf}}^{2 / 3} S^{1 / 2}, \\
\mathrm{CS}=k_{0}\left(\frac{U_{\mathrm{bf}}^{3}}{g h_{\mathrm{bf}} \omega}\right)^{m}, \\
(1-\varphi) \frac{\partial \eta}{\partial t}=-\frac{\partial q_{t}}{\partial x},
\end{gathered}
$$

where $Q_{\mathrm{bf}}$ is the bankfull discharge $\left(\mathrm{m}^{3} / \mathrm{s}\right), B_{\mathrm{bf}}$ is the bankfull channel width, $h_{\mathrm{bf}}$ is the bankfull channel depth, $U_{\mathrm{bf}}$ is the bankfull velocity $(\mathrm{m} / \mathrm{s}), R_{\mathrm{bf}}$ is the bankfull hydraulic radius (m), $S$ is the channel slope, and $n$ is the Manning coefficient determined by the median grain size of the bed material load and channel depth in the form $n=h^{1 / 6} /[18.1+$ $\left.12.31 \lg \left(h / D_{65}\right)\right][45]$. 

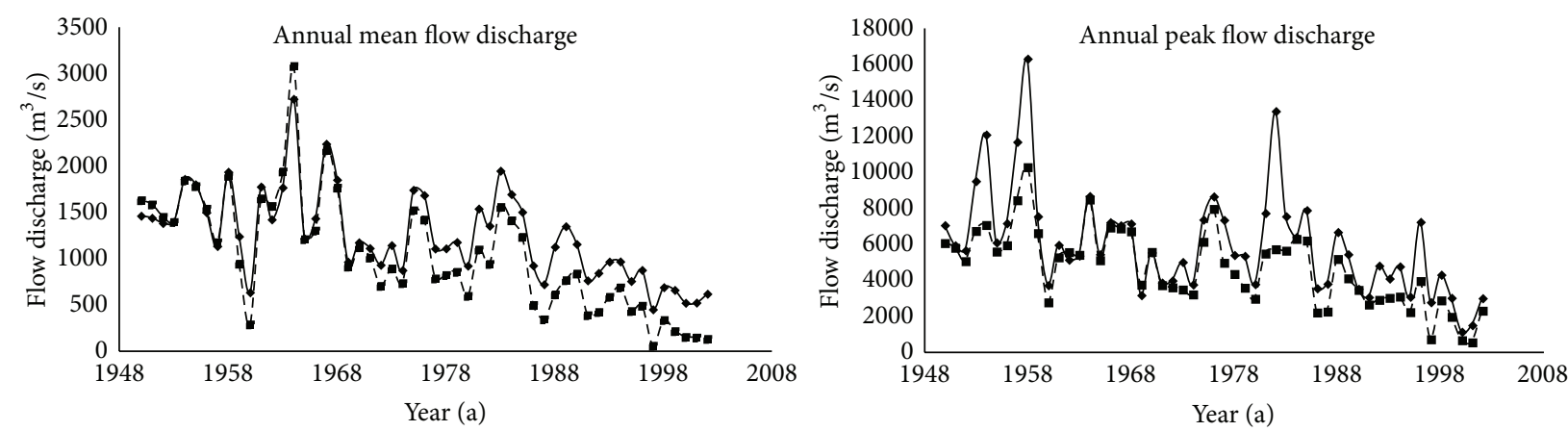

$\rightarrow$ Huayuankou

- - Lijin

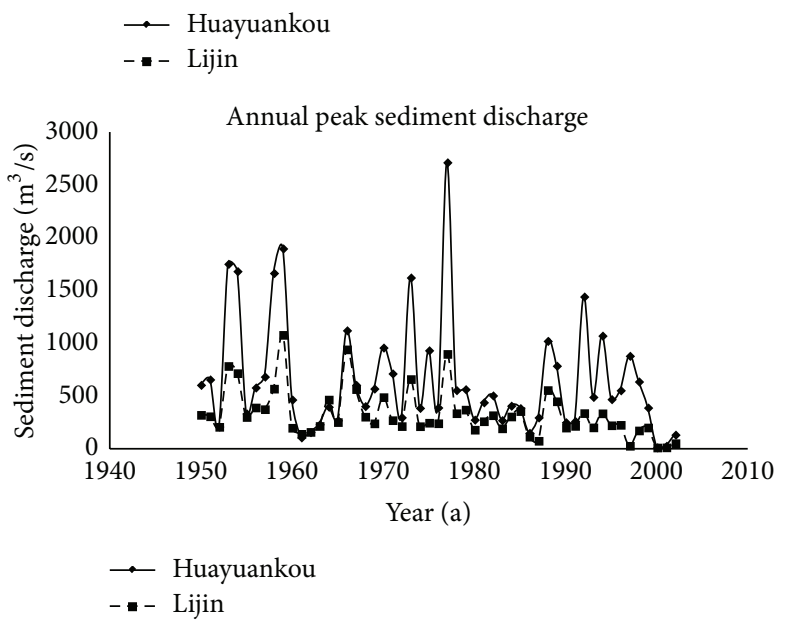

Figure 5: Flow and sediment discharge data at Huayuankou and Lijin Stations.

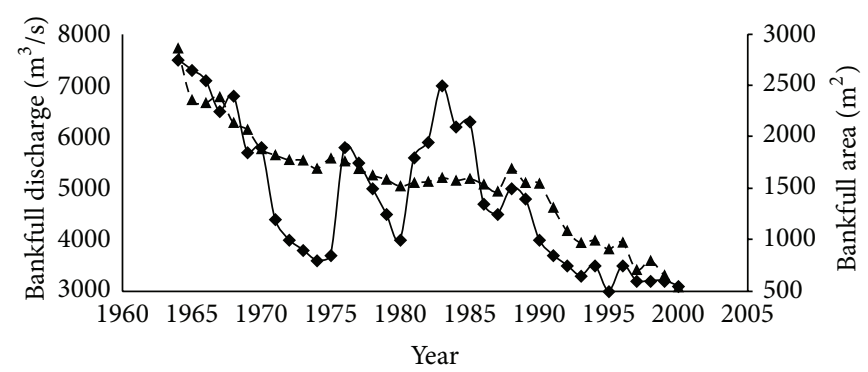

$\rightarrow$ Bankfull discharge

- - Bankfull area

(a)

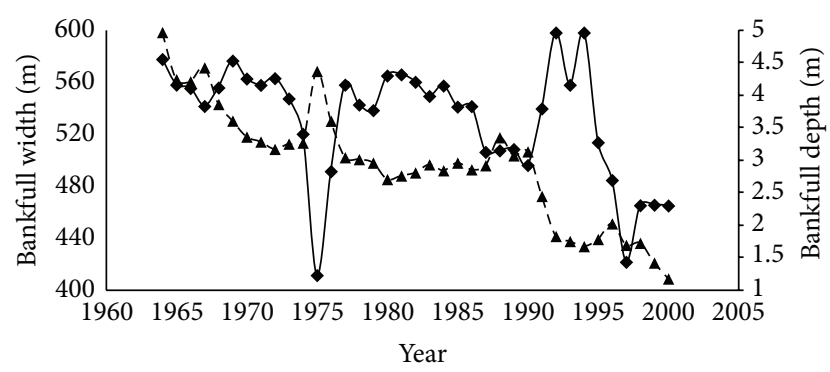

- Bankfull width

- * Bankfull depth

FIGURE 6: Observed bankfull characteristics at Lijin Station: (a) bankfull discharge and area; (b) bankfull width and depth.

TABLE 1: Correlation matrix of the bankfull characteristics at Lijin Station.

\begin{tabular}{lcccc}
\hline & Bankfull discharge & Bankfull area & Bankfull width & Bankfull depth \\
\hline Bankfull discharge & 1 & 0.80 & 0.45 & 0.74 \\
Bankfull area & & 1 & 1 & 0.97 \\
Bankfull width & & & & 0.23 \\
Bankfull depth & & & 1 \\
\hline
\end{tabular}




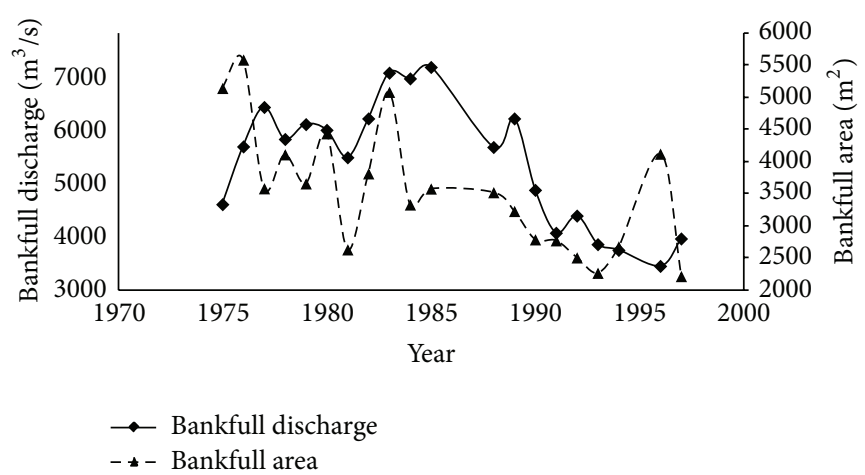

(a)

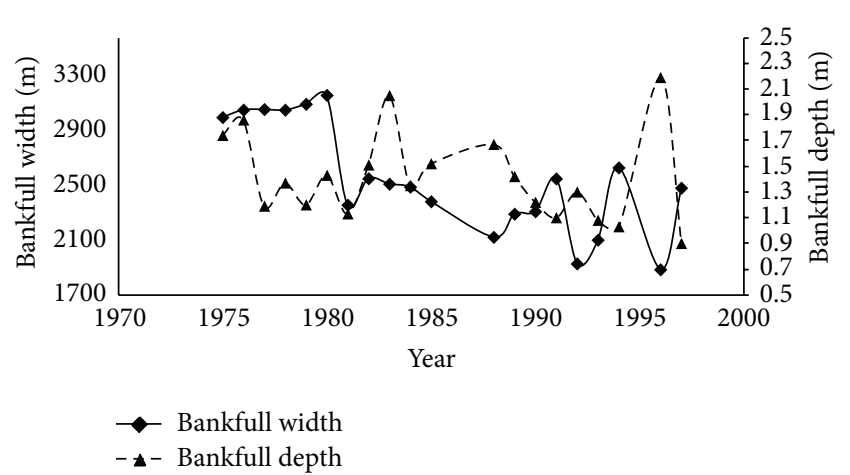

(b)

FIgURE 7: Observed bankfull characteristics at Huayuankou Station: (a) bankfull discharge and area; (b) bankfull width and depth.

TABLE 2: Correlation matrix of the bankfull characteristics at Huayuankou Station.

\begin{tabular}{lcccc}
\hline & Bankfull discharge & Bankfull area & Bankfull width & Bankfull depth \\
\hline Bankfull discharge & 1 & 0.41 & 0.35 & 0.23 \\
Bankfull area & & 1 & 0.52 & 0.79 \\
Bankfull width & & & 1 & -0.08 \\
Bankfull depth & & & 1 \\
\hline
\end{tabular}

Equation (4) is Zhang Ruijin's sediment-carrying capacity formula [46], which is used widely for the LYR, where CS is the sediment concentration $\left(\mathrm{kg} / \mathrm{m}^{3}\right), \omega$ is the sediment settling velocity $(\mathrm{m} / \mathrm{s})$ in muddy water, and $k_{0}$ and $m$ are parameters (at Huayuankou Station, $k_{0}=0.04$ and $m=$ 0.92; at Lijin Station, $k_{0}=0.03$ and $\left.m=0.92\right) . \varphi$ is the riverbed porosity, $\eta$ is the bed elevation $(\mathrm{m}), q_{t}=U_{\mathrm{bf}} h_{\mathrm{bf}} \mathrm{CS}$ is the total sediment transport rate in volume per unit stream width $\left(\mathrm{m}^{2} / \mathrm{s}\right)$, and $x$ is the streamwise coordinate. Of these equations, (5) (i.e., the Exner equation) is for unsteady flow, whereas the others are for steady flows. This is consistent with the fact that the adjustment of the channel form takes much longer than that of the flow and sediment conditions.

These four governing equations involve two independent variables, $Q$ and CS, but five dependent variables in the bankfull state, $B_{\mathrm{bf}}, h_{\mathrm{bf}}, U_{\mathrm{bf}}, S_{\mathrm{bf}}$, and $\eta$. On a medium timescale of $10^{0}-10^{1}$ years, $S$ changes less than $B_{\mathrm{bf}}$ and $h_{\mathrm{bf}}$. As $S_{\mathrm{bf}}$ is fixed, over long periods of time for a given $Q$ and $C S$, the expected channel cross-section can be obtained in terms of $B_{\mathrm{bf}}$ and $h_{\mathrm{bf}}$.

For an alluvial river like the LYR, $R_{\mathrm{bf}} \approx h_{\mathrm{bf}}$ when $B_{\mathrm{bf}} \gg$ $h_{\mathrm{bf}}$. Under these circumstances, the bankfull depth is

$$
\left(\frac{\mathrm{CS}}{k_{0}}\right)^{1 / m} g \omega S^{-1.5}=h_{\mathrm{bf}}^{0.5}\left[18.1+12.31 \lg \left(\frac{h_{\mathrm{bf}}}{D_{65}}\right)\right]^{3}
$$

The left-hand side of (6) is calculated from known data, and the right-hand side of the equation is an increasing function of $h_{\mathrm{bf}}$. A trial method can be used to obtain the value of $h_{\mathrm{bf}}$. Then, $B_{\mathrm{bf}}$ and $U_{\mathrm{bf}}$ can be obtained as

$$
\begin{aligned}
U_{\mathrm{bf}} & =\left[18.1+12.31 \lg \left(\frac{h_{\mathrm{bf}}}{D_{65}}\right)\right] h_{\mathrm{bf}}^{0.5} S^{0.5}, \\
B_{\mathrm{bf}} & =\frac{Q}{\left[18.1+12.31 \lg \left(h_{\mathrm{bf}} / D_{65}\right)\right] h_{\mathrm{bf}}^{1.5} S^{0.5}} .
\end{aligned}
$$

From (6) and (7), $B_{\mathrm{bf}}$ and $h_{\mathrm{bf}}$ are determined by the incoming steady flow and sediment discharge. Nevertheless, for alluvial rivers like the LYR, the flow discharge and sediment volume are not steady on intra- or interannual timescales. As a result, series of $B_{\mathrm{bf}}$ and $h_{\mathrm{bf}}$ should be expected instead of a fixed value. In other words, a dynamic equation including $\partial B_{\mathrm{bf}} / \partial t$ and $\partial h_{\mathrm{bf}} / \partial t$ is needed. This is the key problem to be addressed in this paper.

We rewrite (5) in integral form

$$
(1-\varphi) \int_{0}^{L} \frac{\partial A_{\mathrm{bf}}}{\partial t} d x=(1-\varphi) L \frac{\partial A_{\mathrm{bf}}}{\partial t}=\int_{0}^{L} \frac{\partial Q_{s}}{\partial x} d x
$$

where $L$ is the length of the river reach and $Q_{s}=B q_{t}$ is the volumetric sediment transport rate $\left(\mathrm{m}^{3} / \mathrm{s}\right)$. With the assumption of a rectangular channel, we have

$$
\frac{1}{A_{\mathrm{bf}}} \frac{\partial A_{\mathrm{bf}}}{\partial t}=\frac{1}{h_{\mathrm{bf}}} \frac{\partial h_{\mathrm{bf}}}{\partial t}+\frac{1}{B_{\mathrm{bf}}} \frac{\partial B_{\mathrm{bf}}}{\partial t} .
$$

For rivers in a stationary state, the relationship between the geometrical dimension (i.e., $B$ and $h$ ) and water discharge $Q$ that passes through this cross-section takes the form $[8,47]$

$$
B_{\mathrm{bf}}=a Q_{\mathrm{bf}}^{\alpha}, \quad h_{\mathrm{bf}}=b \mathrm{Q}_{\mathrm{bf}}^{\beta},
$$


where $a$ and $b$ are coefficients that vary with the characteristics of the river basin. For the statistical results of most alluvial rivers across the world [8], $\alpha$ and $\beta$ are exponents, usually with $\alpha=0.5$ and $\beta=0.33$.

For a nonstationary state, $Q_{\mathrm{bf}}$ is a time-dependent variable, and steady values of $B_{\mathrm{bf}}$ and $h_{\mathrm{bf}}$ do not exist. Nonetheless, the relations between bankfull channel geometry and flow discharge still work as

$$
B_{\mathrm{bf}}(t)=a \mathrm{Q}_{\mathrm{bf}}(t)^{\alpha}, \quad h_{\mathrm{bf}}(t)=b \mathrm{Q}_{\mathrm{bf}}(t)^{\beta} .
$$

A plot of the channel response processes is shown in Figure 8, which shows a theoretical situation where the change of water occurs by skipping from one value to another and the channel geometry parameters $\left(B_{\mathrm{bf}}\right.$ or $\left.h_{\mathrm{bf}}\right)$ change synchronously. Nevertheless, a process connects the past bankfull values to the current ones. In this process, the value of $B$ or $h$ is neither the past bankfull value nor the current one. It is also a bankfull value including two impact input processes: the past flow process and current one. Here, we sought a rule that describes the transition between the two stable states.

Equation (11) is differentiated at time $t$

$$
\frac{\partial B_{\mathrm{bf}}}{\partial t}=a \alpha Q_{\mathrm{bf}}^{\alpha-1} \frac{\partial Q_{\mathrm{bf}}}{\partial t}, \quad \frac{\partial h_{\mathrm{bf}}}{\partial t}=b \beta Q_{\mathrm{bf}}^{\beta-1} \frac{\partial \mathrm{Q}_{\mathrm{bf}}}{\partial t},
$$

leading to

$$
\frac{1}{\alpha B_{\mathrm{bf}}} \frac{\partial B_{\mathrm{bf}}}{\partial t}=\frac{1}{\beta h_{\mathrm{bf}}} \frac{\partial h_{\mathrm{bf}}}{\partial t}
$$

The final form is

$$
\begin{aligned}
& \frac{1}{B_{\mathrm{bf}}} \frac{\partial B_{\mathrm{bf}}}{\partial t}=\frac{\alpha}{\alpha+\beta} \frac{1}{A_{\mathrm{bf}}} \frac{\partial A_{\mathrm{bf}}}{\partial t}, \\
& \frac{1}{h_{\mathrm{bf}}} \frac{\partial h_{\mathrm{bf}}}{\partial t}=\frac{\beta}{\alpha+\beta} \frac{1}{A_{\mathrm{bf}}} \frac{\partial A_{\mathrm{bf}}}{\partial t} .
\end{aligned}
$$

The computational model in a reach of the LYR is shown in Figure 9. There, inlet and outlet data appear from the entrance and exit stations of the reach. $\mathrm{CS}_{0}$ and $\mathrm{CS}$ are the sediment transport capacity $\left(\mathrm{kg} / \mathrm{m}^{3}\right)$ of the two stations; $Q$ is the flow discharge of the reach $\left(\mathrm{m}^{3} / \mathrm{s}\right), D_{65}$ is the grain size of the bed material load in the $65 \%$ range $(\mathrm{mm})$, and $L$ is the length of the reach $(\mathrm{m})$.

\section{Results and Discussion}

4.1. Simulation Results. From Jinan Station to the Lijin Station, the model uses the daily water and sediment discharge data from the 1964 to 2000: the bed slope $S=0.0001, \gamma=$ $9800 \mathrm{~kg} /\left(\mathrm{m}^{2} \cdot \mathrm{s}^{2}\right)$, and $D_{65}$ is observed and changed with time every year as shown in Table 3 . The simulation results are shown in Figure 10.

Figure 10 shows that two types of year cause nonnegligible

\begin{tabular}{|c|c|c|}
\hline Year & Huayuankou/mm & Lijin/mm \\
\hline 1964 & 0.009 & 0.014 \\
\hline 1965 & 0.027 & 0.014 \\
\hline 1966 & 0.015 & 0.015 \\
\hline 1967 & 0.02 & 0.018 \\
\hline 1968 & 0.027 & 0.021 \\
\hline 1969 & 0.016 & 0.009 \\
\hline 1970 & 0.018 & 0.012 \\
\hline 1971 & 0.02 & 0.017 \\
\hline 1972 & 0.02 & 0.019 \\
\hline 1973 & 0.018 & 0.018 \\
\hline 1974 & 0.019 & 0.021 \\
\hline 1975 & 0.021 & 0.026 \\
\hline 1976 & 0.015 & 0.023 \\
\hline 1977 & 0.019 & 0.014 \\
\hline 1978 & 0.018 & 0.016 \\
\hline 1979 & 0.016 & 0.016 \\
\hline 1980 & 0.018 & 0.017 \\
\hline 1981 & 0.018 & 0.027 \\
\hline 1982 & 0.018 & 0.023 \\
\hline 1983 & 0.022 & 0.029 \\
\hline 1984 & 0.022 & 0.021 \\
\hline 1985 & 0.023 & 0.021 \\
\hline 1986 & 0.018 & 0.012 \\
\hline 1987 & 0.015 & 0.008 \\
\hline 1988 & 0.02 & 0.015 \\
\hline 1989 & 0.024 & 0.018 \\
\hline 1990 & 0.018 & 0.015 \\
\hline 1991 & 0.017 & 0.016 \\
\hline 1992 & 0.028 & 0.016 \\
\hline 1993 & 0.022 & 0.021 \\
\hline 1994 & 0.029 & 0.018 \\
\hline 1995 & 0.024 & 0.022 \\
\hline 1996 & 0.022 & 0.02 \\
\hline 1997 & 0.027 & 0.016 \\
\hline 1998 & 0.021 & 0.021 \\
\hline 1999 & 0.02 & 0.012 \\
\hline 2000 & 0.005 & 0.029 \\
\hline
\end{tabular}
errors. The first type is the years with low flow discharge and high sediment load, such as 1973 and 1997. In 1973, the annual sediment load at Lijin Station was 1.2 billion tons per
TABLE 3: Grain size of $D_{65}$ at Lijin and Huayuankou Stations.

year or $50 \%$ more than the mean value in the past 50 years. The annual flow volume was 28.15 billion $\mathrm{m}^{3}$ per year or $10 \%$ less than the mean value in the past 50 years. In 1997, the annual sediment load at Lijin Station was 0.016 billion tons per year or $98 \%$ less than the mean value in the past 50 years. The annual flow volume was 1.86 billion $\mathrm{m}^{3}$ per year, with 227 days in the zero-flow state. In these years, deposition along the river occurred more heavily at the outlet. This was the main reason why the observed bankfull width was reduced and the calculated value was not. The second type was years with overflood events, such as what occurred in 1967 and 1988. In 1967, the maximum daily discharge was $8510 \mathrm{~m}^{3} / \mathrm{s}$ and the observed bankfull discharge (after the flood 

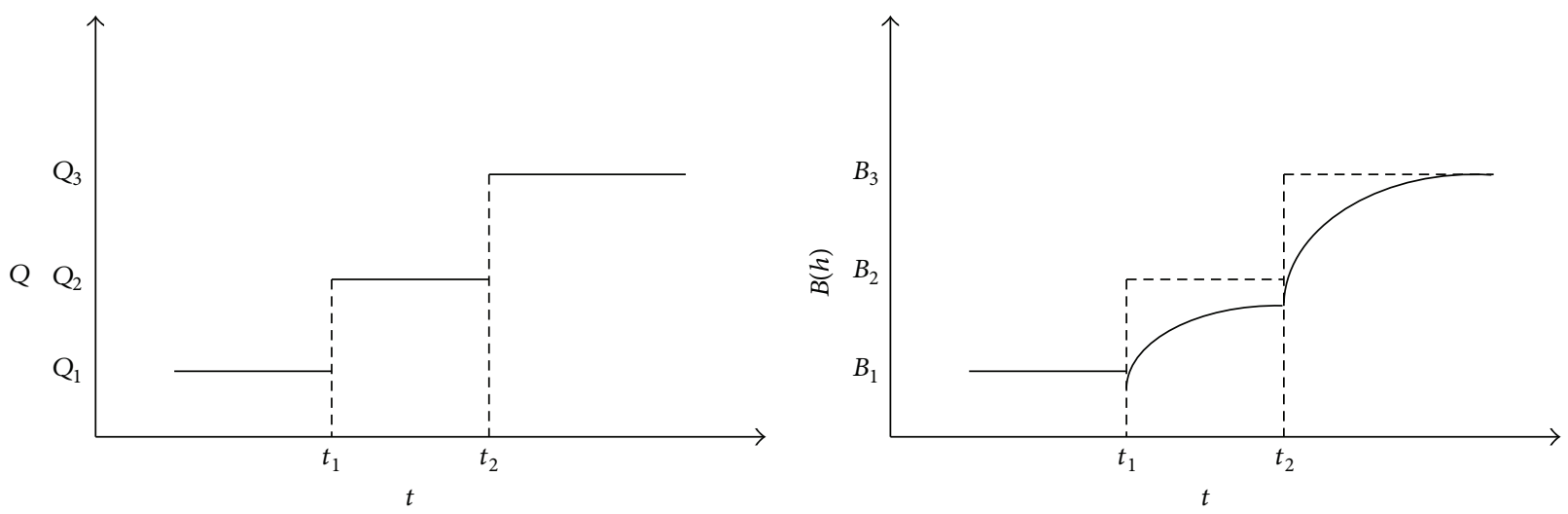

FIGURE 8: Channel response processes for the change of water and sediment flow.

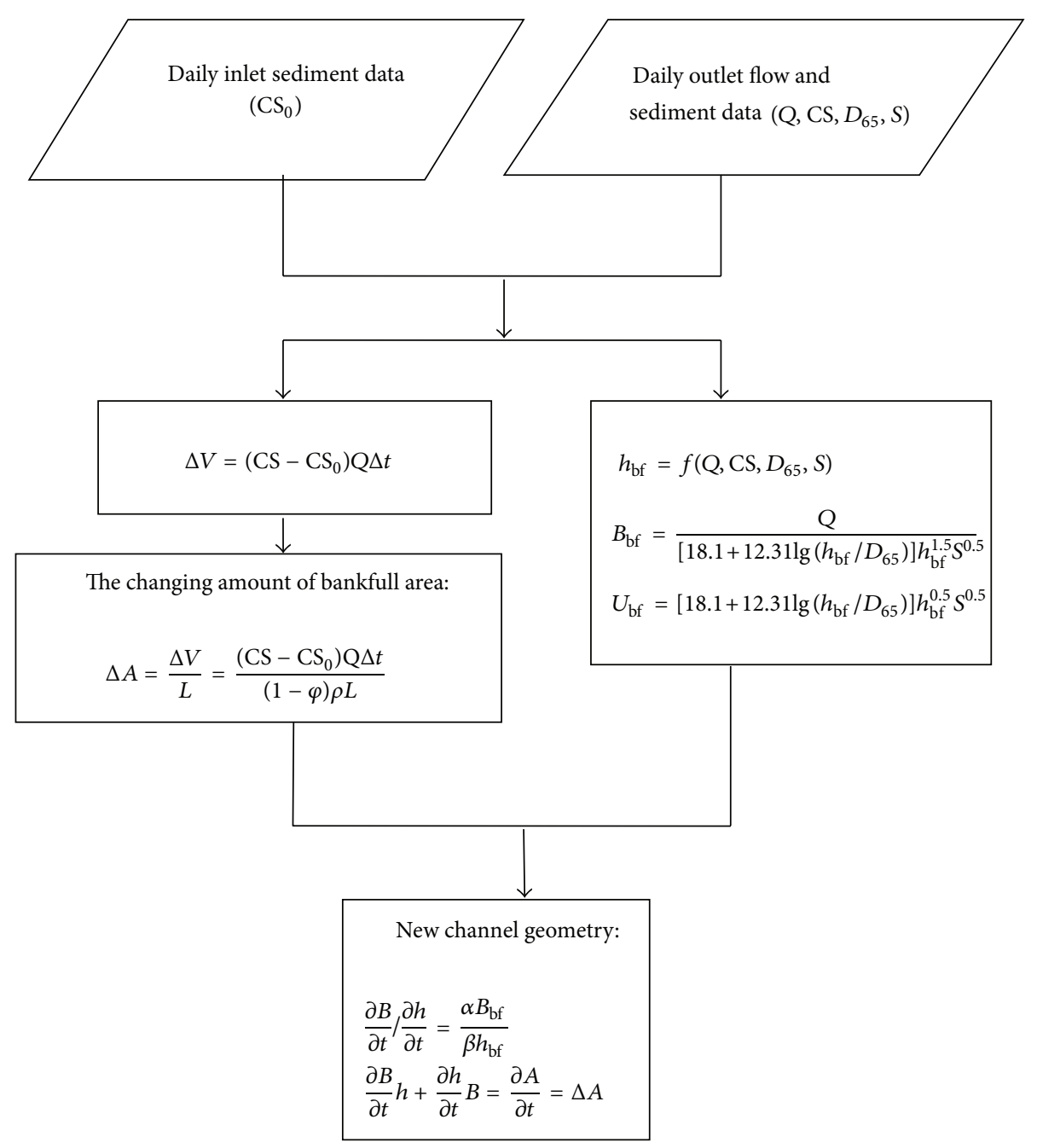

FIGURE 9: Computational process of the bankfull area computational model.

season) was $7500 \mathrm{~m}^{3} / \mathrm{s}$. In 1988 , the maximum daily discharge was $5220 \mathrm{~m}^{3} / \mathrm{s}$ and the observed bankfull discharge (after the flood season) was $5000 \mathrm{~m}^{3} / \mathrm{s}$. However, overbank flood events were less important than the larger sediment load and smaller flow volume from the error analysis at Lijin Station. One explanation for the smaller impact might be the fact that the overbank flood volume was not much larger than the bankfull flood at the river outlet.

The daily water and sediment discharge data for Xiaolangdi and Huayuankou Stations from 1976 to 1997 was 


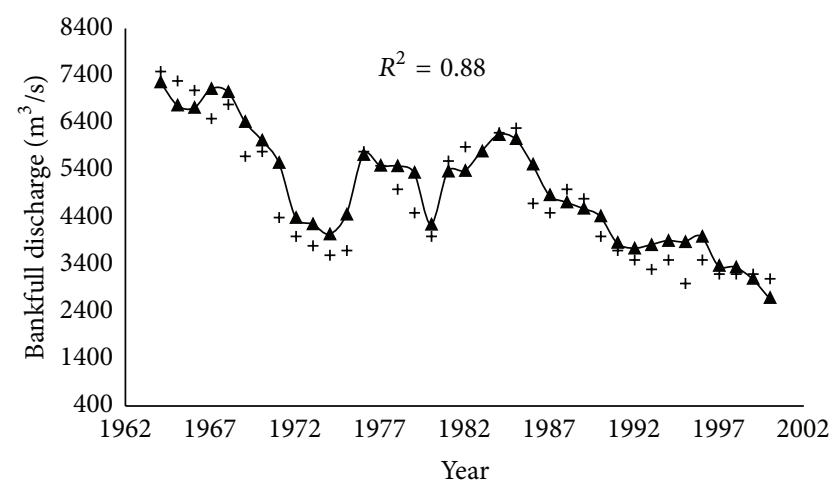

(a)

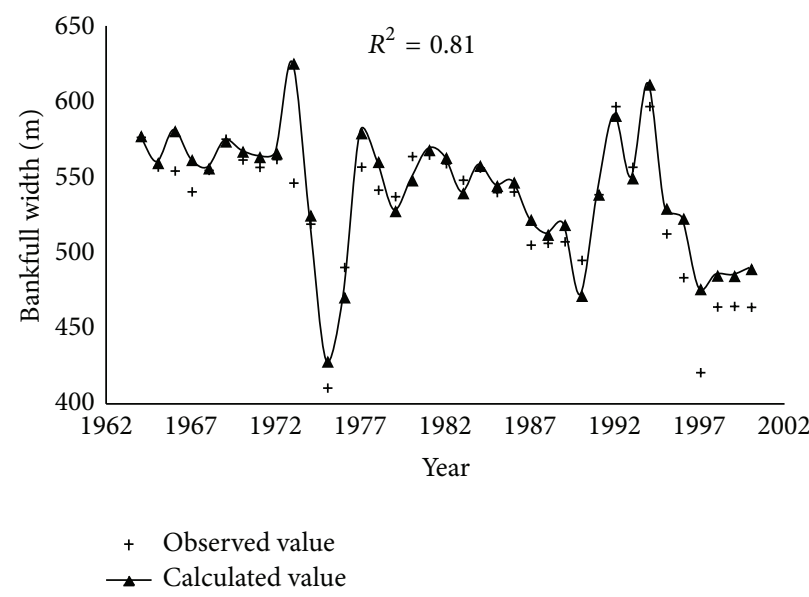

(c)

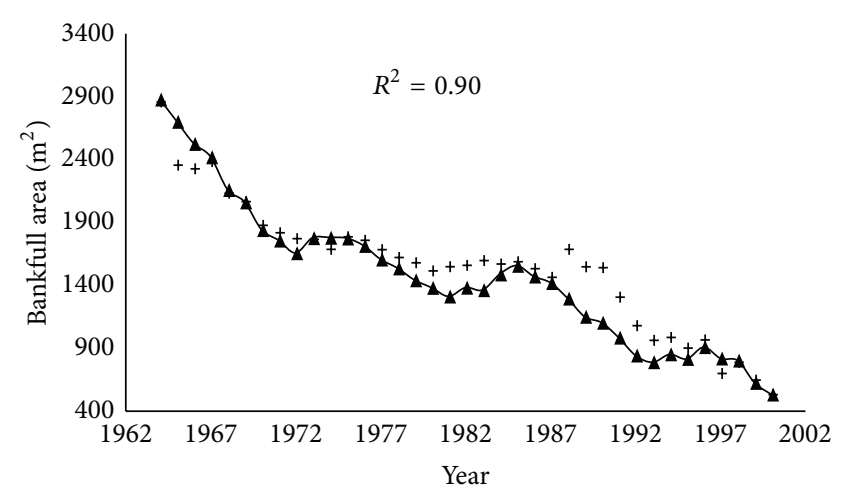

(b)

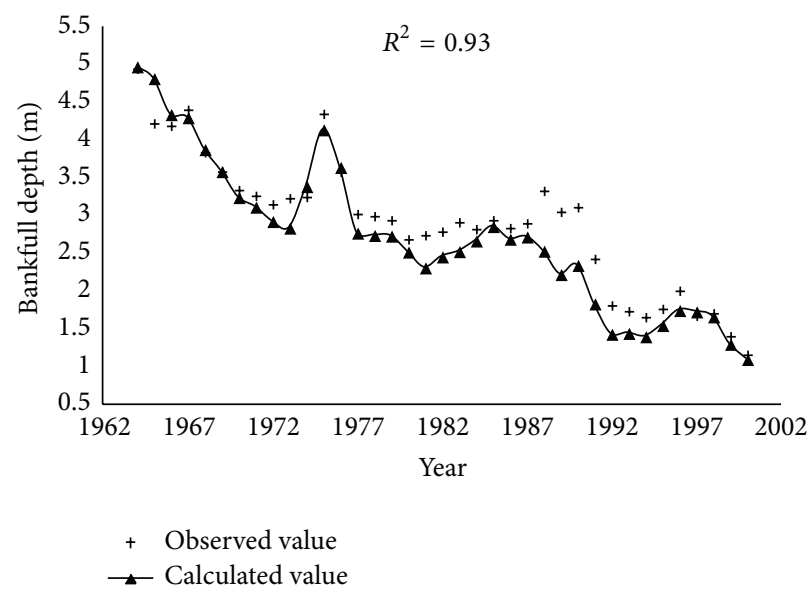

(d)

FIGURE 10: Bankfull computational results at Lijin Station for 38 years: bankfull (a) discharge; (b) area; (c) width; and (d) depth.

used in the model, together with the daily water discharge data of Heishiguan and Wuzhi Stations. The simulation results are shown in Figure 11.

The calculated errors at Huayuankou station were more obvious than those at Lijin station. Besides the first type, which included 1987 and 1992, the second type, which included $1976 \sim 1977,1981 \sim 1983,1988$, and 1996, had more impact on the errors. $1981 \sim 1983$ may be taken as an example: the max daily discharge was $7760,13,400$, and $7580 \mathrm{~m}^{3} / \mathrm{s}$, respectively, and the bankfull discharge (after the flood season) was 5320,6000 , and $6800 \mathrm{~m}^{3} / \mathrm{s}$. Three years of overbank flood events caused obvious river width expansion, which the methods in this paper cannot reflect.

From Figures 10 and 11, however, the calculated values still agree well with the observed values $\left(R^{2}>0.7\right)$. This shows that the assumptions and methods adopted in this model are reasonable in some sense.

\subsection{Accuracy Impact Factors for Simulations}

4.2.1. Lateral Inflow. Two tributaries in the XiaolangdiHuayuankou reach and the Yiluo and Qin Rivers affected the flow and sediment discharge in the reach. Given the lack of daily sediment concentration data, a simplified study is required.
According to the statistical data from 1960 to 1996, the annual average sediment discharge of the Yiluo River (Heishiguan station) is $0.092 \times 10^{8} t$, accounting for $0.9 \%$ of that in the main stream of the LYR. The annual average sediment discharge of the Qin River (Wuzhi station) is $0.039 \times 10^{8} t$, accounting for $0.4 \%$ of that in the main stream of the LYR. Therefore, these two rivers are considered to be clear in the calculation for this section. This simplification might affect the accuracy in some years when the sediment load cannot be ignored.

4.2.2. Overbank Flood. Differences exist in the scour and silting mechanisms between overbank and normal floods. Scouring occurs when the water level rises, while silting occurs when the water level falls. Floodplain silting with channel scouring is common during overbank flood periods in the LYR.

For overbank floods with a low sediment load, for example, the flood that occurred from July 31 to August 8, 1982, the peak discharge at Huayuankou station was $15,300 \mathrm{~m}^{3} / \mathrm{s}$ and the average sediment concentration was $67 \mathrm{~kg} / \mathrm{m}^{3}$. This caused 0.217 billion tons of sediment to be deposited in the floodplain and 0.15 billion tons to be scoured from the main channel in the Huayuankou-Aishan reach. 


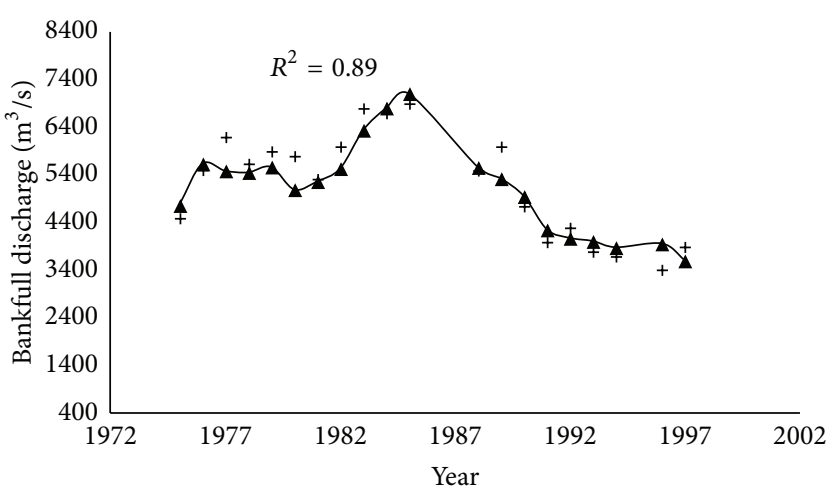

(a)

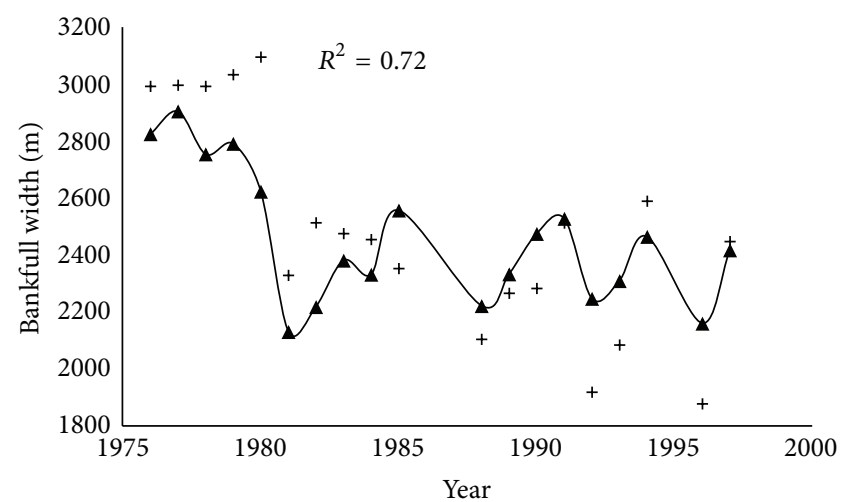

+ Observed value

$\rightarrow$ Calculated value

(c)

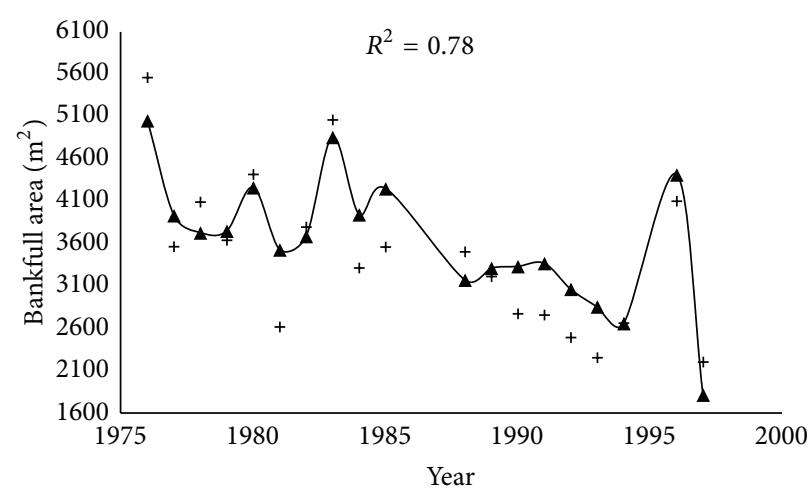

(b)

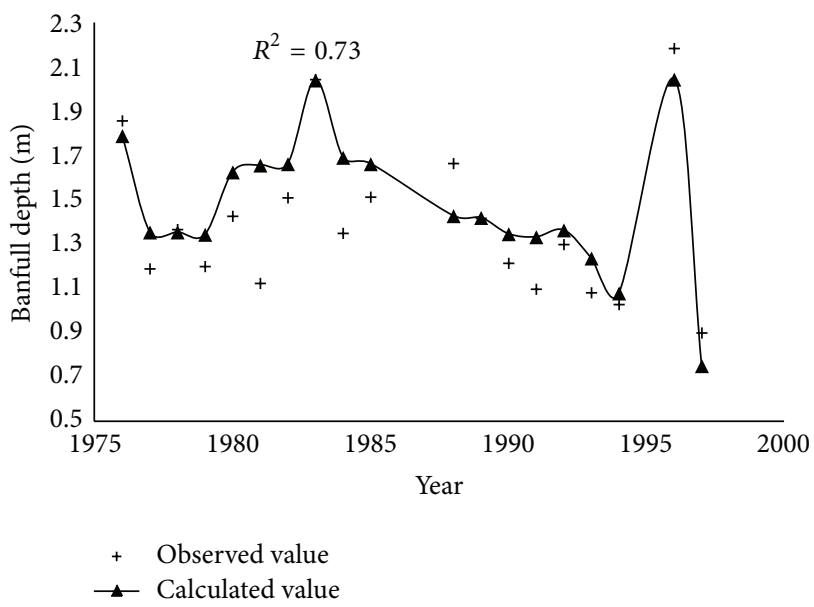

(d)

FIGURE 11: Bankfull computational results at Huayuankou station for 22 years: bankfull (a) discharge; (b) area; (c) width; and (d) depth.

For overbank floods with high sediment load, for example, the flood that occurred in 1977, the peak discharge at Huayuankou station was $10,800 \mathrm{~m}^{3} / \mathrm{s}$ and the average sediment concentration was $437 \mathrm{~kg} / \mathrm{m}^{3}$. This caused the amount of sediment deposited in the main channel to be three times that deposited in the floodplain in the Huayuankou-Aishan reach.

Consequently, the methods used in this paper are not suitable for overbank situations. The key issue is that the distribution of resistance in the floodplain and main channel is unknown. A simplified statistical method is used to deal with overbank flood events. For flows with a high sediment concentration, sediment is deposited all along the river, and a distributing coefficient $K=V_{1} / V_{2}$ reflecting the deposition ratio between the floodplain and main channel is calibrated against all years. Here, $V_{1}$ is the deposition volume in the main channel $\left(\mathrm{m}^{3}\right)$ and $V_{2}$ is in the floodplain.

For flows with a high sediment concentration, sediment is deposited all along the river $(K=0.32)$, while for flows with a low sediment concentration, the main channel is scoured, the floodplain is deposited, and $K=-0.51$. According to statistical data, the criterion for high sediment loads is $300 \mathrm{~kg} / \mathrm{m}^{3}$.
4.2.3. Channel Shape of a Uniform Reach. Here, the chosen river reach is assumed to be uniform so that the depositing or eroding sediment volume can be distributed along the reach evenly. This assumption is much more acceptable in the Jinan-Lijin reach than in the Xiaolangdi-Huayuankou reach, because there is a valley channel beyond Xiaolangdi Station that affects the sediment distribution along the XiaolangdiHuayuankou reach. This might be an important impact factor for the accuracy of the model applied to Huayuankou station.

\section{Conclusions}

(1) Based on the equations for stable alluvial rivers, namely, the Exner equation, flow continuity, the momentum, and sediment concentration conservation equations and assuming that the riverbed slope is constant on middle timescales $\left(10^{0}-10^{1}\right.$ years), we found stationary geomorphic relations for time-varying fluvial processes. We obtained a timedependent relation for the channel geometry given nonstationary alluvial processes.

(2) The final solutions from the equations for stable alluvial rivers simply reflect the adjusted direction 
of channel geometry. The adjusted magnitude of the hydraulic geometry each day is determined by the daily input of depositing or eroding sediment volumes. The direction and magnitude give the final channel shape.

(3) Using daily flow and sediment data to determine the adjustment direction and magnitude, the variation in the bankfull characteristics for Lijin and Huayuankou Stations in the LYR were calculated. The final results agreed closely $\left(R^{2}>0.7\right)$ with the observed values. This implies that the assumptions are acceptable and the method is applicable for the reservoir and channel regulation in the LYR.

(4) Compared with the rate-law and hydrodynamic methods, the proposed method enables multiple dependent variables and the input of detailed hydrological data for long-term simulations. However, because of those assumptions for simplification, the model we provided also has some limitations. Firstly, it cannot be applied to a dramatic time-varying fluvial procedure like an overbank flow or a hyperconcentration flood, only fitting for a quasisteady fluvial process. Secondly, the time-step of one day is still large for a physics-based model which smoothes the deviation of inner-daily flood process. Thirdly, the key equation in this model is derived by the experiential relations between channel geometry and hydraulic relations, which is not verified in theory. These limitations are the main sources of the model error and will be our next work in the future.

\section{Conflict of Interests}

The authors declare that there is no conflict of interests regarding the publication of this paper.

\section{Acknowledgments}

This study was supported financially by the China Ministry of Science and Technology through the Key Project in the National Science \& Technology Pillar Program in the Twelfth Five-year Plan Period of China (Grant no. 2012BAB02B02). It was supported by the Open Program Fund of MWR Key Laboratory of Yellow River Sedimentation of the Yellow River Conservancy Commission.

\section{References}

[1] G. Lacey, "Flow in alluvial channels with sandy mobile beds," Proceedings of the Institute of Civil Engineers, vol. 11, pp. 145-164, 1958.

[2] D. B. Simons and M. L. Albertson, "Uniform water conveyance channels in alluvial materials," Journal of the Hydraulics Division, vol. 86, pp. 33-71, 1960.

[3] J. X. Xu, "The water fluxes of the Yellow River to the sea in the past 50 years, in response to climate change and human activities," Environmental Management, vol. 35, no. 5, pp. 620631, 2005.
[4] W. L. Graf, "The rate law in fluvial geomorphology" American Journal of Science, vol. 277, no. 2, pp. 178-191, 1977.

[5] G. P. Williams and M. G. Wolman, Downstream Effects of Dams on Alluvial Rivers, Geological Survey Professional Paper no. 1286, U.S. Government Printing Office, Washington, DC, USA, 1984.

[6] A. Simon, "A model of channel response in disturbed alluvial channels," Earth Surface Processes \& Landforms, vol. 14, no. 1, pp. 11-26, 1989.

[7] C. E. Thorn and M. R. Welford, "The equilibrium concept in geomorphology," Annals of the Association of American Geographers, vol. 84, no. 4, pp. 666-696, 1994.

[8] D. Knighton, Fluvial Forms and Processes: A New Perspective, Arnold, London, UK, 1998.

[9] N. Surian and M. Rinaldi, "Morphological response to river engineering and management in alluvial channels in Italy," Geomorphology, vol. 50, no. 4, pp. 307-326, 2003.

[10] M. P. Mosley, "Semi-determinate hydraulic geometry of river channels, South Island, New Zealand," Earth Surface Processes \& Landforms, vol. 6, no. 2, pp. 127-137, 1981.

[11] C. Gippel, "Changes in stream channel morphology at tributary junctions, Lower Hunter Valley, New South Wales," Australian Geographical Studies, vol. 28, no. 2, pp. 291-307, 1985.

[12] J. E. Pizzuto, "Flow variability and the bankfull depth of sandbed streams of the American Midwest," Earth Surface Processes \& Landforms, vol. 11, no. 4, pp. 441-450, 1986.

[13] G. L. Heritage, L. J. Broadhurst, and A. L. Birkhead, "The influence of contemporary flow regime on the geomorphology of the Sabie River, South Africa," Geomorphology, vol. 38, no. 3-4, pp. 197-211, 2001.

[14] C. Groves and J. Meiman, "Weathering, geomorphic work, and karst landscape evolution in the Cave City groundwater basin, Mammoth Cave, Kentucky," Geomorphology, vol. 67, no. 1-2, pp. 115-126, 2005.

[15] B. Wu, G. Wang, and J. Xia, "Case study: delayed sedimentation response to inflow and operations at Sanmenxia Dam," Journal of Hydraulic Engineering, vol. 133, no. 5, pp. 482-494, 2007.

[16] B. Wu, G. Wang, J. Xia, X. Fu, and Y. Zhang, "Response of bankfull discharge to discharge and sediment load in the Lower Yellow River," Geomorphology, vol. 100, no. 3-4, pp. 366-376, 2008

[17] B. Wu, J. Xia, X. Fu, Y. Zhang, and G. Wang, "Effect of altered flow regime on bankfull area of the Lower Yellow River, China," Earth Surface Processes \& Landforms, vol. 33, no. 10, pp. 15851601, 2008.

[18] B. Wu, S. Zheng, and C. R. Thorne, "A general framework for using the rate law to simulate morphological response to disturbance in the fluvial system," Progress in Physical Geography, vol. 36, no. 5, pp. 575-597, 2012.

[19] T. J. Pietsch and G. C. Nanson, "Bankfull hydraulic geometry; the role of in-channel vegetation and downstream declining discharges in the anabranching and distributary channels of the Gwydir distributive fluvial system, southeastern Australia," Geomorphology, vol. 129, no. 1-2, pp. 152-165, 2011.

[20] S. Zheng, B. S. Wu, C. R. Thorne, and A. Simon, "Morphological evolution of the North Fork Toutle River following the eruption of Mount St. Helens, Washington," Geomorphology, vol. 208, pp. 102-116, 2014.

[21] A. D. Howard, "Equilibrium and time scales in geomorphology: application to sand-bed alluvial streams," Earth Surface Processes \& Landforms, vol. 7, no. 4, pp. 303-325, 1982. 
[22] B. Yu and M. G. Wolman, "Some dynamic aspects of river geometry," Water Resources Research, vol. 23, no. 3, pp. 501-509, 1987.

[23] C. Leon, P. Y. Julien, and D. C. Baird, "Case study: equivalent widths of the middle Rio Grande, New Mexico," Journal of Hydraulic Engineering, vol. 135, no. 4, pp. 306-315, 2009.

[24] Y. Ma, H. Q. Huang, G. C. Nanson, Y. Li, and W. Yao, "Channel adjustments in response to the operation of large dams: the upper reach of the lower Yellow River," Geomorphology, vol. 147148, pp. 35-48, 2012.

[25] E. Pasche and G. Rouvé, "Overbank flow with vegetatively roughened flood plains," Journal of Hydraulic Engineering, vol. 111, no. 9, pp. 1262-1278, 1985.

[26] S. E. Darby and C. R. Thorne, "Predicting stage-discharge curves in channels with bank vegetation," Journal of Hydraulic Engineering, vol. 122, no. 10, pp. 583-586, 1996.

[27] E. Mosselman, "Morphological modeling of rivers with erodible banks," Hydrological Processes, vol. 12, no. 8, pp. 1357-1370, 1998.

[28] S. E. Darby, "Effect of riparian vegetation on flow resistance and flood potential," Journal of Hydraulic Engineering, vol. 125, no. 5, pp. 443-454, 1999.

[29] N. Rüther and N. R. B. Olsen, "Three-dimensional modeling of sediment transport in a narrow $90^{\circ}$ channel bend," Journal of Hydraulic Engineering, vol. 131, no. 10, pp. 917-920, 2005.

[30] T. Helmiö, "Unsteady 1D flow model of compound channel with vegetated floodplains," Journal of Hydrology, vol. 269, no. 1-2, pp. 89-99, 2002.

[31] G. Wang, J. Xia, and B. Wu, "Numerical simulation of longitudinal and lateral channel deformations in the braided reach of the Lower Yellow River," Journal of Hydraulic Engineering, vol. 134, no. 8, pp. 1064-1078, 2008.

[32] J. Xia, B. Wu, G. Wang, and Y. Wang, "Estimation of bankfull discharge in the Lower Yellow River using different approaches," Geomorphology, vol. 117, no. 1-2, pp. 66-77, 2010.

[33] D. Jia, X. Shao, H. Wang, and G. Zhou, "Three-dimensional modeling of bank erosion and morphological changes in the Shishou bend of the middle Yangtze River," Advances in Water Resources, vol. 33, no. 3, pp. 348-360, 2010.

[34] Z.-H. Sun, Y.-T. Li, Y. Huang, and K.-C. Gao, "Fluvial process of sandbars and shoals in branching channels of the middle Yangtze River," Journal of Hydraulic Engineering, vol. 42, no. 12, pp. 1398-1406, 2011.

[35] D. Motta, J. D. Abad, E. J. Langendoen, and M. H. Garcia, "A simplified 2D model for meander migration with physicallybased bank evolution," Geomorphology, vol. 163-164, pp. 10-25, 2012.

[36] K. Asahi, Y. Shimizu, J. Nelson, and G. Parker, "Numerical simulation of river meandering with self-evolving banks," Journal of Geophysical Research: Earth Surface, vol. 118, no. 4, pp. 22082229, 2013.

[37] B. Wu, G. Wang, J. Ma, and R. Zhang, "Case study: river training and its effects on fluvial processes in the Lower Yellow River, China," Journal of Hydraulic Engineering, vol. 131, no. 2, pp. 8596, 2005.

[38] Z. X. Xu, K. Takeuchi, and H. Ishidaira, "Monotonic trend and step changes in Japanese precipitation," Journal of Hydrology, vol. 279, no. 1-4, pp. 144-150, 2003.

[39] D. S. Wilks, Statistical Methods in the Atmospheric Sciences, Academic Press, Oxford, UK, 3rd edition, 2011.

[40] J. M. Hooke, "River channel adjustment to meander cutoffs on the River Bollin and River Dane, northwest England," Geomorphology, vol. 14, no. 3, pp. 235-253, 1995.
[41] A. Simon and C. R. Thorne, "Channel adjustment of an unstable coarse-grained stream: opposing trends of boundary and critical shear stress, and the applicability of extremal hypotheses," Earth Surface Processes \& Landforms, vol. 21, no. 2, pp. 155-180, 1996.

[42] G. A. Richard, Quantification and prediction of lateral channel adjustments downstream from Cochiti Dam [Ph.D. thesis], Colorado State University, Rio Grande, NM, USA, 2001.

[43] G. V. Wilkerson and G. Parker, "Physical basis for quasiuniversal relationships describing bankfull hydraulic geometry of sand-bed rivers," Journal of Hydraulic Engineering, vol. 137, no. 7, pp. 739-753, 2011.

[44] W. K. Annable, C. C. Watson, and P. J. Thompson, "Quasiequilibrium conditions of urban gravel-bed stream channels in southern Ontario, Canada," River Research and Applications, vol. 28, no. 3, pp. 302-325, 2012.

[45] C. H. Hu, Complex Channel Response and Variation of 13 Flow and Sediment Processes of the Yellow River, Science Press, Beijing, China, 1st edition, 2005.

[46] W. Zhang, G. Lu, and X. Pan, "The analysis and discussion of sediment transport capacity formula," Applied Mechanics and Materials, vol. 188, pp. 259-263, 2012.

[47] E. D. Andrews, "Effective and bankfull discharges of streams in the Yampa River basin, Colorado and Wyoming," Journal of Hydrology, vol. 46, no. 3-4, pp. 311-330, 1980. 


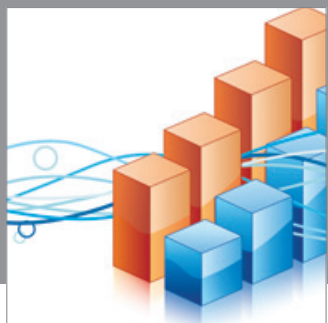

Advances in

Operations Research

mansans

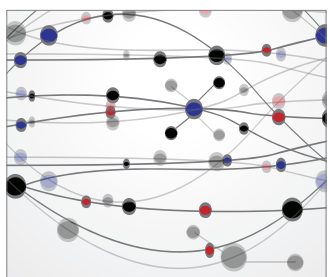

The Scientific World Journal
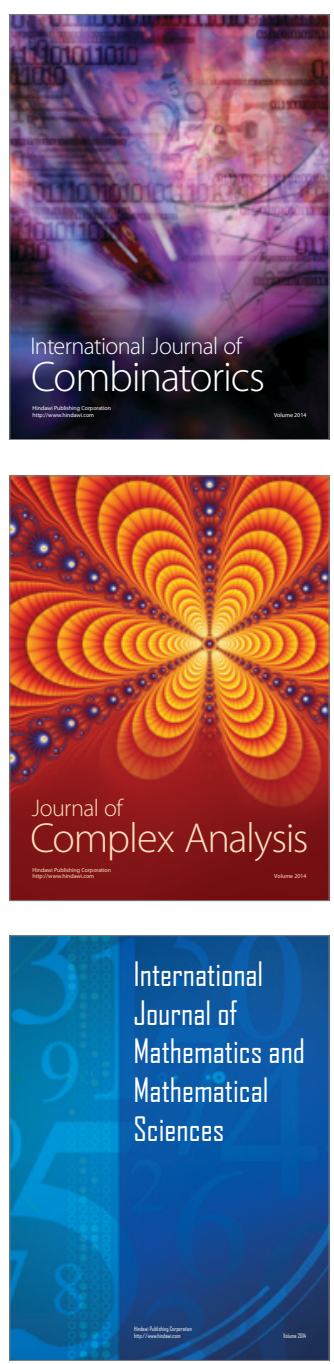
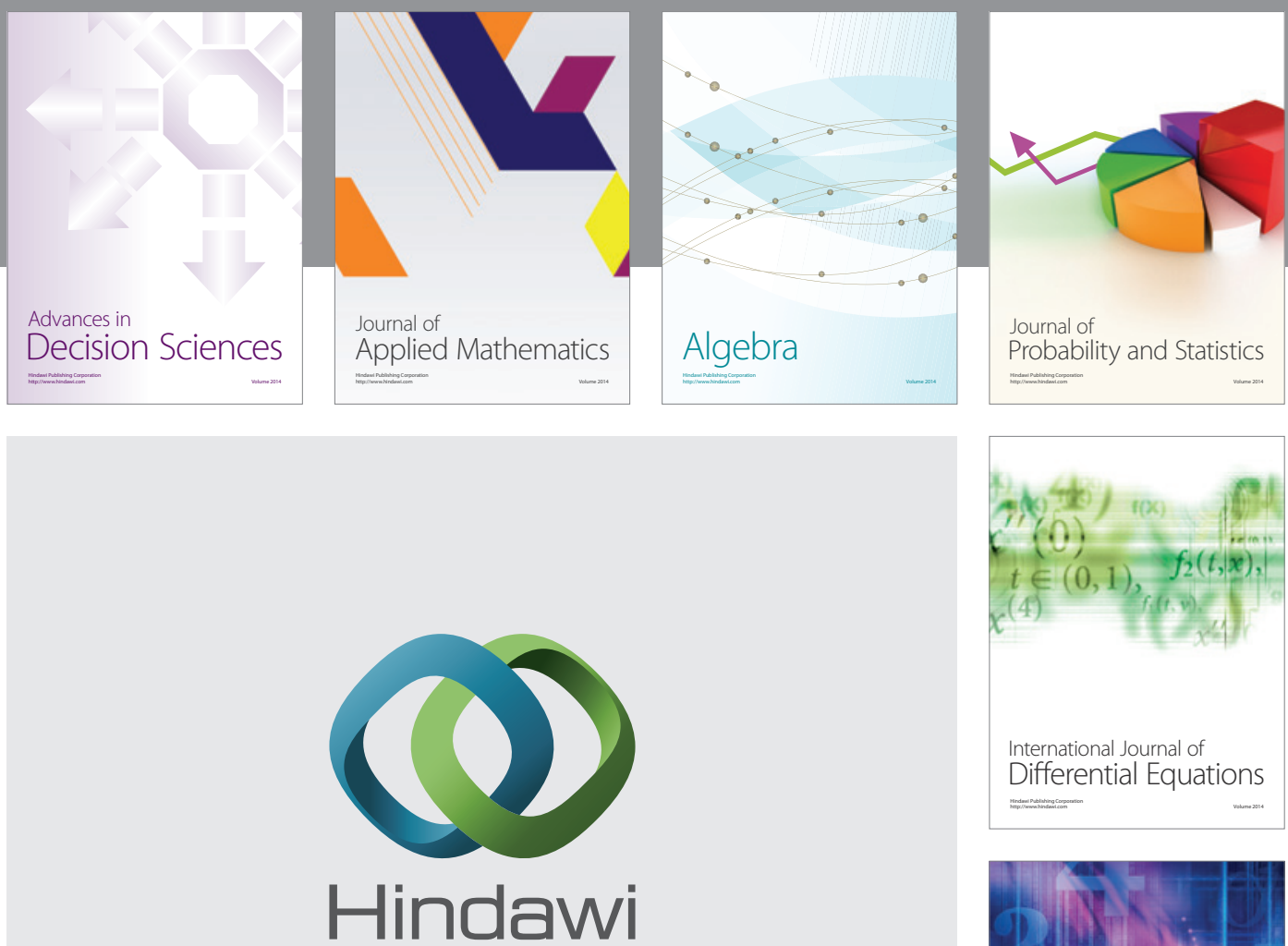

Submit your manuscripts at http://www.hindawi.com
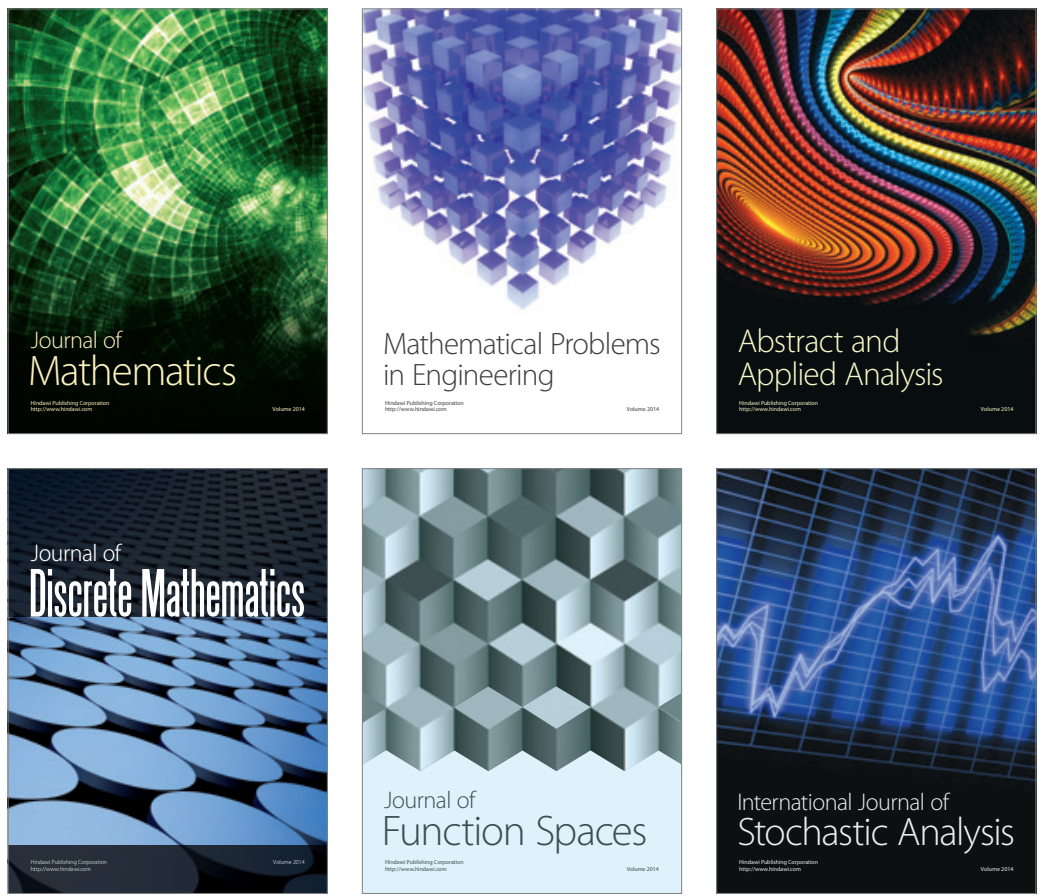

Journal of

Function Spaces

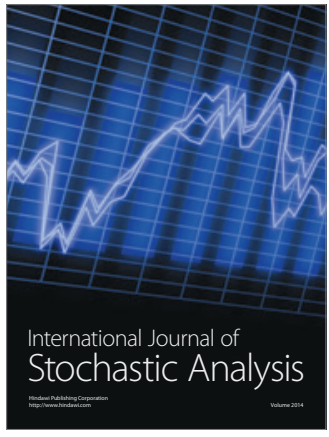

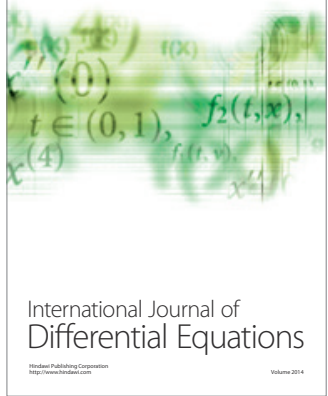
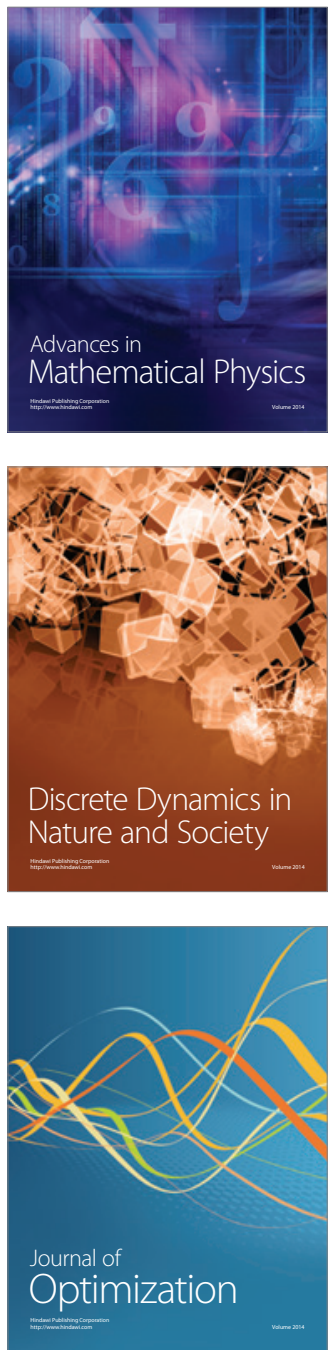